\title{
Hallmark Sporting Events as a Vehicle for Promoting the Sustainable Development of Regional Tourism: Strategic Perspectives from Stakeholders
}

\author{
Huei-Fu Lu (D)
}

Citation: Lu, H.-F. Hallmark Sporting Events as a Vehicle for Promoting the Sustainable Development of Regional Tourism: Strategic Perspectives from Stakeholders. Sustainability 2021, 13, 3460. https://doi.org/ $10.3390 /$ su13063460

Academic Editor: Nicholas Wise

Received: 22 February 2021

Accepted: 18 March 2021

Published: 20 March 2021

Publisher's Note: MDPI stays neutral with regard to jurisdictional claims in published maps and institutional affiliations.

Copyright: (C) 2021 by the author. Licensee MDPI, Basel, Switzerland. This article is an open access article distributed under the terms and conditions of the Creative Commons Attribution (CC BY) license (https:// creativecommons.org/licenses/by/ $4.0 /)$.
Department of Sport Management, Aletheia University, New Taipei City 25103, Taiwan; au4299@au.edu.tw; Tel.: +886-2-26212121

\begin{abstract}
Although hosting sporting events has received considerable attention and the important connection between sporting events and urban development has been highlighted, most studies have focused on mega sporting events, and the controversy around the benefits of hosting mega sporting events is also increasing. To promote regional sport tourism, this study explores the strategic perspectives of stakeholders on hosting hallmark sporting events for the regional development of sport tourism. In-depth interviews were conducted with 11 representatives from stakeholder groups to discuss the role and essence of hallmark sporting events in promoting regional tourism. Archival material, including event organizing documents and information, was used to enhance the reliability of the qualitative analysis. Four strategic perspectives are proposed to illustrate the inter-relationships between hallmark sporting events and the sustainable development of regional tourism. These perspectives can be used as a management procedure to improve event operations for event managers. This study's main contribution is the proposal of development goals and proper execution processes for hosting hallmark sporting events for the sustainable development of regional tourism, and the cultivation of effective synergy between local business activities and stakeholders.
\end{abstract}

Keywords: hallmark sporting events; sustainable development; sport tourism; stakeholders; event management

\section{Introduction}

In the 21st century, sports and tourism constitute a potential economic driving force in today's society and have great potential for generating large-scale economic benefits [1]. According to the guidelines of sustainable tourism development [2], the principle of sustainability involves the environmental, economic, and social-cultural aspects of tourism development. Especially when developing a sustainable strategy for tourism development, an appropriate balance must be established between these three aspects to ensure its longterm sustainability [2-4]. Similar to hosting sporting events, it needs to take full account of the current and future economic, social, and environmental impacts, addressing the needs of the industry, the environment, host communities, and stakeholders [5-7]. In recent decades, sporting events have played a critical role in the development of cities, regions, and even countries [8]. The significance of sporting events is increasing day by day, which also highlights the critical linkage between the events and the sustainable development of regional tourism $[9,10]$. The assessment of the long-term social and economic benefits of sporting events has gradually become a mainstream research topic [5]. Sporting events can be divided into different scales and types, ranging from small regional level sporting events to mega sporting events. Mega sporting events have always been recognized as the type most likely to bring considerable benefits [11].

Previous studies concerning tourism and urban development have focused on mega sporting events, such as the Olympics and the World Cup [12-15]. However, criticism and controversy around the benefits of hosting these events are also increasing [16-20], 
especially with regards to the negative environmental and social impacts [21-24]. As residents may only be able to witness the hosting of mega events once in their lifetime, they often feel alienated from mega events. However, small-scale sporting events can be held regularly, and become a more influential part of communities [5]. Gibson et al. [25] emphasized that the preparatory work of small-scale sporting events is consistent with the host community's development goals for infrastructure and human and cultural capital, thereby enabling tourism sustainable development. Although there are fewer economic benefits of smaller events, their negative impacts are relatively minor. Smaller events help alleviate the seasonal boom in tourism, use existing infrastructure, and require less public funding, thereby generating more reliable income [26]. In other words, the essence of small-scale sporting events is more in line with the core value of sustainable development.

In recent years, the promotion of hallmark sporting events (hereafter, HSEs) has been integrated with tourism in various regions in Taiwan. It has become the branch of the tourism industry with the highest growth potential [27]. Based on unique local environmental characteristics, sport tourism in different regions of Taiwan should take different directions for potential development. The Mercuries Taiwan Masters Invitational Golf Tournament (hereafter, MTMIGT), a well-known annual HSE in North Taiwan, is hosted as "The Masters" in the United States. Sponsored by Mercuries and Associates Holding Company (hereafter, MAHC), the MTMIGT has been held for 34 consecutive years, since 1987. As one of the oldest golf tournaments in Taiwan and Asia, it is in the same league as the Chinese Open and the Chinese Professional Championships. Further, it is significant in the Asian and international golf circles. It is held every year in SeptemberOctober at the Tamsui Golf Course in Northern Taiwan. The tournament also features "sightseeing on the go" and "golf day" activities, and provides off-campus visits to primary school students. Thus, through guided tours, it popularizes golf activities, arousing local enthusiasm and support for the sport, while encouraging the participation of residents. Over the years, this tournament has gained familiarity with the residents of Tamsui [28].

Although the advocacy for tourism sustainable development is prevalent across smallscale events, HSEs, and large-scale sporting events, most of the research thus far has focused on the economic and tourism impacts of mega events [29,30]. It is unclear how or whether HSEs actually affect regional tourism development in the host community. Therefore, this study aims to reveal the role of HSEs in the sustainable development of regional tourism from the stakeholders' perspective. By observing and exploring the particularity of the combination of hosting the MTMIGT and sustainable regional tourism, the substantive significance and management policy of HSEs is summarized for the reference of local authorities.

\section{Literature Review}

\subsection{The Essence of HSEs}

The development of HSEs is closely related to tourism and special festive activities [31]. The earliest and most widely cited definition came into being after Ritchie and Beliveau [32] studied the Quebec Winter Carnival as an HSE. An HSE refers to one-off or repeated events that are held within a limited duration of time, with the main purpose of increasing the visibility, attractiveness, and business opportunities of the venue in the short or long term. The key to the success of such events consists of their uniqueness, reputation, or importance, in order to create benefits and attract public attention [33]. Graham et al. [34] defined HSEs as sporting events that mark an important historical anniversary. Based on their perspectives, an HSE can only be a one-off event. Getz [35] addressed that HSEs can be repetitive events with the importance of tradition, attraction, image or reputation for the host region. HSEs can generate a market competitive advantage for venues, communities, or destinations. As time goes by, an HSE will be integrated with the destination.

Ritchie and Crouch [36] listed the world-renowned "hallmark" events, such as the Boston Marathon, Kentucky Derby, US Masters, Mardi Gras in New Orleans, Oktoberfest in Munich, Cowboys Music Festival in Calgary, the running of the bulls in Pamplona, and 
championships such as Wimbledon. Getz [37] believed that a "hallmark" indicates a symbol of event quality or certification. Therefore, an event is a symbolic indicator of its organizer, venue, or area, which brings public attention to its status as a permanent and regular activity. Getz [38] later redefined a "hallmark" event as a repeating event of considerable importance in terms of traditional customs, attractiveness, public image, or publicity. It also offers a competitive advantage to the hosting site, community, or destination. Over time, the relationship between the event and the hosting site becomes inseparable. Getz et al. [39] first proposed the definition and concept of HSEs in sport tourism and sporting event management, highlighting the role of an HSE in the community and tourism environment. They constructed three main output goals of HSEs (attractiveness, brand image, and community), and three main process objectives (sustainability, marketing, and organizational ownership), which serve as a model that can be applied by the community and other sport tourism organizers. Frost [31] believes that the Indianapolis 500 is also an HSE, and adds that a number of European cities use traditional cultural activities as hallmarks to make their cities more fashionable or avant-garde sightseeing destinations through popular cultural activities. By summarizing previous perspectives, the essence of HSEs can be defined as one-off or repeated events endowed with both international and local characteristics, and capable of enhancing the visibility, attractiveness, and business opportunities of the host. The legacy of HSEs may have profound impacts on regional development.

\subsection{Sporting Events and Sustainable Regional Tourism}

There are a number of studies directly or indirectly exploring sporting events and the sustainable development of host regions [25,30,40-44]. Sporting events are organized according to the needs of each region, and these needs are often related to the local cultural, social, and economic background $[5-7,45]$. The development of sport tourism will have a significant and positive impact on regional industries and the promotion of regional economic development [46-48]. Sherwood [49] studied the economic impact of 85 events held in Australia and found inconsistent conclusions with respect to the economic impacts of various events. Moreover, the social and cultural impacts of the regional events have attracted more and more attention. Conversely, sporting event tourism in the host region may bring negative economic, socio-cultural, and environmental impacts, including inflation, excessive dependence on tourism, deterioration of government finances, disruption of the labor market, and increased external costs [50].

From a societal perspective, sport tourism involves an extensive range of issues, many of which relate to the views of residents on community participation [51-53], social equity [40], cultural development [54,55], and health promotion [56,57]. For example, the term "psychic income" is used to show that hosting a sporting event can produce excitement, pride, and pleasure for citizens of a country [58]; the hosting of an event can convert "spiritual income" into long-term social capital. Since social capital has a stimulating effect, its reinforcement strengthens other types of capital [59]. Thus, the public can actively participate in sports, generating pride, enthusiasm, and social cohesion [60]. Kim and Morrison [61] found that many cities hold related celebrations during the event, generating national pride and enthusiasm. Carey et al. [62] addressed that various communities will enhance their social cohesiveness by participating in sporting events and promoting the participation of various communities in public affairs and related activities, thereby generating social influences, such as improvement in the quality of life of underprivileged groups. Moreover, work related to hosting sporting events, such as venue construction, medical services, drug testing, information services, and media broadcasting may improve local industrial technologies and enhance the skills and personal development of workers involved, thereby contributing to the long-term development of society [63,64]. Kim et al. [65] constructed a six-factor model to evaluate residents' cognitions related to the economic benefits, civic pride in the community, community development, economic costs, transportation issues, and safety risks during large-scale sport tourism. The evidence re- 
vealed the multi-faceted nature of social influence, which helps with better understanding the local perceptions toward the importance of sport tourism.

Sport tourism helps members establish their identity and a sense of community pride. Residents of host regions display pride when they introduce their cities and participate as volunteers [66]. Furthermore, the host city improves its infrastructure, and consequently, the quality of life of its residents, when it prepares for the event and the arrival of tourists $[30,67,68]$. Andersson and Lundberg [69] pointed out that in increasing the visibility and image of its tourist destinations, a region often organizes a series of sporting events and cultural activities. Through these activities, it attracts tourists and allows residents to become consumers or serve as volunteers. The various stakeholders also contribute to the success of the event in different ways, as they work toward their expectations. Kaplanidou and Vogt [70] explored the factors that contribute to the success of sporting events through the perspectives of event sponsors and spectators who had experienced small sporting events, and explained how events and tourist destination impressions interact to affect sport tourism behavior. Malchrowicz-Mośko and Poczta [42] presented the meaning of sporting events for the tourism industry and the importance of sporting events at a small scale, as well as heritage sporting events, for the sustainable development of tourist destinations. Such events will affect tourist revival and improvement of the regions' image. Thus, smaller sporting events often aim to promote public awareness and encourage active participation among residents.

To assess the impact of sporting events on sustainable development, May [71] first adopted the framework of the triple bottom line to reveal the impact of sporting events on the environment. In recent decades, the sport tourism industry has considered the environment as the core of tourist products. Ecotourism and sustainable development are emerging across all sectors of the tourism industry [72]. Goeldner and Ritchie [73] emphasized that long-term protection of the social and environmental concerns of a scenic spot is more important than short-term economic gains. Bourdeau et al. [74] highlighted that pollution is caused by adventure sports in French mountainous areas and suggested the adoption of sustainable development to protect fragile ecosystems. In many countries, opening golf courses is generally regarded as a feasible way to attract foreign tourists and increase the income of residents. However, the severe socio-economic and environmental impact that golf courses may have is often ignored [75]. Lim and Patterson [76] proposed combining golf tourism with regional characteristics as a strategy for developing niche markets in island countries. Ahmed et al. [77] highlighted the environmental impact of South African beach sport tourism and increased surfing activities and called for increased environmental education. Collins and Flynn [78] proposed an "ecological footprint" to measure the environmental sustainability of the FA Cup finals, explaining that this measurement tool could support policymakers and event organizers in holding sustainable activities through the formulation and evaluation of policy plans. Collins et al. [21] indicated that although the event organizers often consider the importance of environmental resources to the event, the environmental impact of mega sporting events often occurs over a long period of time after the event, making a quantitative evaluation complicated and confusing. Collins et al. [79] used two different approaches to test the environmental sustainability and economic effects of the Tour de France 2007, for the promoters to understand how to leverage tourism consumption and discuss the effects of the sporting event on the economy and the environment. Zhang and Park [80] tested the most important factors to consider in the development of a sustainable and responsible HSE. Andersson et al. [81] applied the contingent valuation method to evaluate "use" and "non-use" monetary values, and carbon footprint analysis, with respect to consumption and waste, provided a systematic comparison of activities and allowed monitoring of sustainability efforts.

\subsection{Leveraging Sporting Events for Regional Tourism}

Previous studies have contributed to the leveraging issues of mega sporting events such as the Olympics and the World Cup [82-86]. Chalip [59] proposed creating a sense 
of celebration and three main ways to promote the leverage of a sporting event, namely creating informal social opportunities, generating auxiliary activities, and using visual cues and symbols in the community to enhance the sense of celebration. Effective synergy between the local tourism industry, sports organizations, and residents is necessary to leverage sporting events and create a celebratory atmosphere. O'Brien and Chalip $[87,88]$ proposed new leverage strategies for sporting events, aiming to achieve the triple bottom line for the community where the events are hosted. Nonetheless, the impacts of HSEs have not received enough attention $[89,90]$.

Similarly, the leverage strategy of a sporting event can also unleash the potential benefits of small and regional events [91]. As Higham [26] advocated, smaller events are more beneficial to the host region than larger events. Host regions try to make use of events of various types and sizes, hoping to achieve similar success. In a related topic, Kruger and Saayman [92] discussed how South Africa's Two Oceans Marathon could be used to create an unforgettable spectator experience. They identified four factors, namely facilities, comfort and visibility, marketing and personnel, and stipulations. Among these, facilities and marketing were the key factors that would lead to a successful and unforgettable audience experience. Kaplanidou and Gibson [93] proposed the factors motivating amateur athletes to participate repeatedly in regular small-scale sporting events. Misener and Mason [94,95] addressed that regional sporting events have the potential to build social capital and promote community development. Ziakas and Costa [48] proposed the use of a combination of regular sports and cultural activities to promote the development of the community and regional economy. Misener [96] further established the theoretical framework for leveraging regional sporting events and pointed out that for the sporting event to benefit the host region, the host community needs to activate certain critical elements among their resources.

\subsection{Stakeholders of Sporting Events}

Stakeholder theory was first proposed by Freeman [97] and was mainly used in the field of management [98]. Afterward, Jones and Wicks [99] provided four principles of the stakeholder theory: (1) there will be many stakeholders in an organization; (2) stakeholder theory focuses on the relationship between the organization and each stakeholder, regarding the process and the result; (3) the interests of all stakeholders have value, and no interest can be imposed on other stakeholders; and (4) the theory is applied to management decision-making. Previous research has discussed the relationship between various stakeholders and the success of sporting events extensively [100-103]. Stakeholders include individuals or groups who have been affected or will be affected by the activities of a sporting event in the past, present, and future [104,105]. Since the assessment of sporting events must rely on the information provided by relevant stakeholders, their needs should be considered in the planning stage [102].

The stakeholders of sporting events include sports organizations, preparatory committees, host cities and governments, delegations, sponsors, the media, and other groups who are affected by the hosting of the events and have a decisive impact on the success of the events. They will consider whether the information and outcome of the events and their personal needs are in harmony with the goals of the events, but conflicts may also arise [106]. Bowdin et al. [107] stated that relevant stakeholders in large-scale sporting events include athletes, international sports associations, sports authorities, local and central governments, government officials, sponsors, the media, the public, and volunteers. According to Reid [101] and Reid and Arcodia [100], the important stakeholders of major sporting events are the business community, community groups, environmentalists, emergency service personnel, governments, event organization groups, residents in the hosting and non-hosting area, shareholders, tourism staff and employed personnel (both by the event or otherwise employed), sponsors, volunteers, the media, and contestants. Therefore, the literature mentioned shows that the stakeholders of an event are the direct or indirect participants involved in the operation of such an event. 


\section{Method}

\subsection{In-Depth Interviews}

Following the framework of Parent [103] and Leopkey and Parent [108] regarding sporting event stakeholders, individuals and organizations were identified. In-depth interviews were conducted following the three dimensions of the interview outline shown in Table 1. Table 2 displays the personal codes and listed organizations of the participant representatives of the interviewees. The interviewer first contacted the stakeholder groups and asked if they were willing to be interviewed. A total of 11 interviewees were invited from the stakeholder groups to consider the diverse perspectives of stakeholders, including local government, academia, sponsors, event volunteers, and residents, to derive sustainable development strategies for regional tourism. This was subject to their considerable involvement and professionalism with respect to the MTMIGT, to ensure the validity of the data.

In the process of data sorting, the in-depth interviews were first transcribed and then converted into verbatim manuscripts, which were read repeatedly to arrive at meaningful sentences. These were subjected to a coding process, and sustainable development strategies were classified accordingly. The edited interview transcript was then sent back to the original interviewee for confirmation and modification, to reduce errors in semantic decoding. Finally, within- and between-stakeholder comparisons (similarities and differences) were examined and summarized.

Table 1. Interview outline.

\begin{tabular}{|c|c|}
\hline Dimension & Outline \\
\hline Economic impact & $\begin{array}{l}\text { Regarding the economic impact of the } \\
\text { MTMIGT on the development of tourism in } \\
\text { Tamsui, how does this event create a new } \\
\text { business network for regional sustainable } \\
\text { development? }\end{array}$ \\
\hline Environmental impact & $\begin{array}{l}\text { What impact will the MTMIGT have on the } \\
\text { development of tourism in Tamsui, socially } \\
\text { and culturally? What is the direction and } \\
\text { strategy for sustainable development? } \\
\text { How will the MTMIGT affect the environment } \\
\text { for tourism development in Tamsui? What is } \\
\text { the direction and strategy for sustainable } \\
\text { development? }\end{array}$ \\
\hline
\end{tabular}

1. How is an HSE used to create regional tourism characteristics?

2. What factors in an HSE contribute to or hinder the sustainable development of regional tourism?

3. How can the event organizers or participating units adjust their working relationships to achieve regional tourism development goals?

4. What are the sustainable benefits of regional tourism development brought about by an HSE after the event?

5. What is the strategy for maintaining the local environment after the HSE is held?

6. What is the sustainable development strategy for the workforce and volunteers after the event?

7. What is the development strategy for tourists or residents to maintain their enthusiasm and concern for HSE after the event?

8. Which industries can benefit from sustainable development after the event?

9. What are the possible continuous expenditures after the HSE is held?

10. As opposed to large-scale events, what key points and strategies should an HSE consider for the sustainable development of local tourism? 
Table 2. The selected list of stakeholder groups for in-depth interviews.

\begin{tabular}{|c|c|c|c|}
\hline Code & Job Title & Stakeholder Groups & Institution \\
\hline O1 & CEO & $\begin{array}{l}\text { A representative of the } \\
\text { organizer }\end{array}$ & $\begin{array}{l}\text { Foundation for Taiwan } \\
\text { Masters Golf Tournament }\end{array}$ \\
\hline G1 & Mayor & $\begin{array}{l}\text { Official representative of the } \\
\text { New Taipei City Government }\end{array}$ & $\begin{array}{c}\text { Tamsui District Office, } \\
\text { New Taipei City }\end{array}$ \\
\hline G2 & City councilor & $\begin{array}{l}\text { A representative of New Taipei } \\
\text { City Council }\end{array}$ & $\begin{array}{c}\text { City Council, New Taipei } \\
\text { City }\end{array}$ \\
\hline $\mathrm{R} 1$ & Borough warden & $\begin{array}{c}\text { Resident representative of } \\
\text { Tamsui District, New Taipei } \\
\text { City }\end{array}$ & $\begin{array}{c}\text { Tamsui District, New } \\
\text { Taipei City }\end{array}$ \\
\hline $\mathrm{R} 2$ & Borough warden & $\begin{array}{c}\text { Resident representative of } \\
\text { Tamsui District, New Taipei } \\
\text { City }\end{array}$ & $\begin{array}{c}\text { Tamsui District, New } \\
\text { Taipei City }\end{array}$ \\
\hline $\mathrm{C} 1$ & General manager & Co-organizer representative & Taiwan Golf Club \\
\hline $\mathrm{C} 2$ & Alumni & Volunteer representative & XXXX University \\
\hline S1 & Manager & Sponsor representative & Mercuries Life Insurance \\
\hline $\mathrm{S} 2$ & Shop manager & Sponsor representative & Mercuries Furniture \\
\hline M1 & Dean & $\begin{array}{l}\text { Representatives of scholars } \\
\text { with event management } \\
\text { expertise }\end{array}$ & XXXX University \\
\hline M2 & Professor & $\begin{array}{l}\text { Representatives of scholars } \\
\text { with event management } \\
\text { expertise }\end{array}$ & XXXX University \\
\hline Total & & 11 & \\
\hline
\end{tabular}

\subsection{Data Gathering}

In this study, stakeholders were consulted, and archival material and interviews were taken as the primary sources of data to ensure robustness. Some interviewees provided organizational documents to enrich the study. Archival materials, including official organizing documents and the MTMIGT official website information, were used to increase the reliability of the results. Moreover, interviews complemented this information to reinforce the connotations in the archival materials, in addition to providing elucidation. Data were gathered through semi-structured interviews, which lasted about one hour on average. In contrast to the structured discussion method [109], semi-structured interviews allow the researcher to probe the answers of the interviewee and obtain more information [110].

\section{Results and Discussion}

This study contributes to the literature on sporting events and knowledge of sustainable development in several ways. Through in-depth interviews with stakeholders, the following sub-sections present four strategic perspectives to advance the substantial development of regional sport tourism through the hosting of HSEs, by summarizing the interviewees' responses. Table 3 displays brief descriptions of the strategic perspectives, with quoted examples.

\subsection{Using the HSE to Create Regional Tourism Features}

The MTMIGT has been held for 33 consecutive years at the oldest golf course in Taiwan and has become a regularly featured event of Tamsui as a local carnival festival. Since golf is not a civilian sport, it needs the combined efforts of public entities, academic units, and enterprises to promote it through tourism, enabling easy participation for tourists and residents in the event and allowing them to meet and see golf players at the international level. Therefore, complementary supporting measures need to be presented to create local features for regional sport tourism. During the MTMIGT, new activities could be designed in the future. For example, mini marathons could be held on the periphery of the golf course to attract sports tourists to the area to participate in the grand event, adding 
excitement to the HSE. As sports tourists enter the golf course to watch the game, they could activate sightseeing activities in Tamsui District.

Table 3. The descriptions of the strategic perspectives with quoted examples.

\begin{tabular}{l} 
Strategic Perspectives \\
\hline Using the HSE to Create \\
Regional Tourism Features
\end{tabular}

Quoted Examples

G1: “... The MTMIGT was originally a well-known sporting event and has always been very appealing. Additionally, Tamsui also has many tourist attractions. If we combine the event with the traditional characteristics of Tamsui, we could create an exclusive brand of Tamsui sport tourism ..." C1: “... As long as we create other activities that add to this event, sightseeing activities in Tamsui will gain new momentum. As Tamsui is a small region, it is not difficult to run this event well in such a small community".

C1: “... As Tamsui itself is known as the hometown of golf, the Taiwan Masters should invest in nurturing the next generation of golf players.... The MAHC can sponsor some cultural activities in Tamsui. For example, during the grand worshipping festival, the MAHC can also make some investments to show continued concern for the Tamsui community, as cultural tourism and the tournament in Tamsui could complement each other".

M1: “ ... Companies related to the MAHC can also provide donations to the tournament, schools can act as planning units, and the Tamsui District Office can be the co-organizer. This would be an intelligent and significant combination for the development of local tourism. Golf itself is suitable for all ages. As MAHC is in the business of life insurance, they would want to see people live a long life. Through sports such as golf, people would be able to exercise and increase their lifespan. This is the right combination because such links could help realize the aim of national sports, promote the development of local tourism, and achieve the corporate goals of sponsors".

G1: “... The MTMIGT is held at the first golf course in Taiwan. The event has an incredible view, and it is an excellent opportunity to promote tourism consumption in Tamsui. I think that many factors could promote the sustainable development of tourism in the tournament. There are relatively few obstacles. At most, the event will cause temporary traffic congestions, which the residents will understand ..."

The Critical Factors Facilitating Sustainable Development

The Role of HSE Stakeholder Groups in Realizing Regional Development Goals
C2: “... A sporting event needs to gather human resources, material resources, and financial resources. Therefore, the economic factor is of primary concern. We hope that Taiwan's economic growth will not deteriorate, as this gives impetus for the sustained operation of enterprises. I think that the obstacles also concern sponsors and co-organizers and that the source of funds is a fundamental issue because even a slight hiccup could hinder the sustainable development of tourism".

G2: “... Tamsui has a history of more than 400 years. There are more than 30 historical monuments and buildings, and it has precious social, cultural, and artistic resources. Therefore, Tamsui has excellent potential in terms of tourism development. This aspect is what draws 8 million tourists to Tamsui every year..."

C2: “... Co-organizers of the tournament can form alliances with shops on Tamsui old streets to design multiple sightseeing activities, such as golf walking, stamping after completing an event, and lot-drawing with the stamps, or shopping for event merchandise in the Tamsui business district..." S1: “ ... HSEs enable watching of games, and participating in static sports sightseeing, visiting museums, reviewing the history and celebrities of golf tournament, visiting nearby historical sites such as Fort San Domingo, Oxford College, and going on other nostalgic tours. Furthermore, schools can be integrated into various activities. For the public, it is not only about watching games and savoring beef noodles but also about understanding the development history of golf in Taiwan, going shopping and sightseeing in the old streets, enjoying shopping discounts, buying souvenirs, etc". C2: “... The MTMIGT is an event, and it must be considered a spiritual hallmark so that the event has a spiritual and a cohesive goal. There must be horizontal coordination and a complementary mechanism to witness successful sustainable development in the organization and realize the development of regional tourism aims. ... Of course, we also play another important role; that is, to improve the competency of sports management. The better the event is organized, the more it will generate positive effects ..." 
Table 3. Cont.

\begin{tabular}{|c|c|}
\hline Strategic Perspectives & Quoted Examples \\
\hline $\begin{array}{l}\text { Sustained Benefits for } \\
\text { Regional Tourism } \\
\text { Development after the } \\
\text { HSE }\end{array}$ & 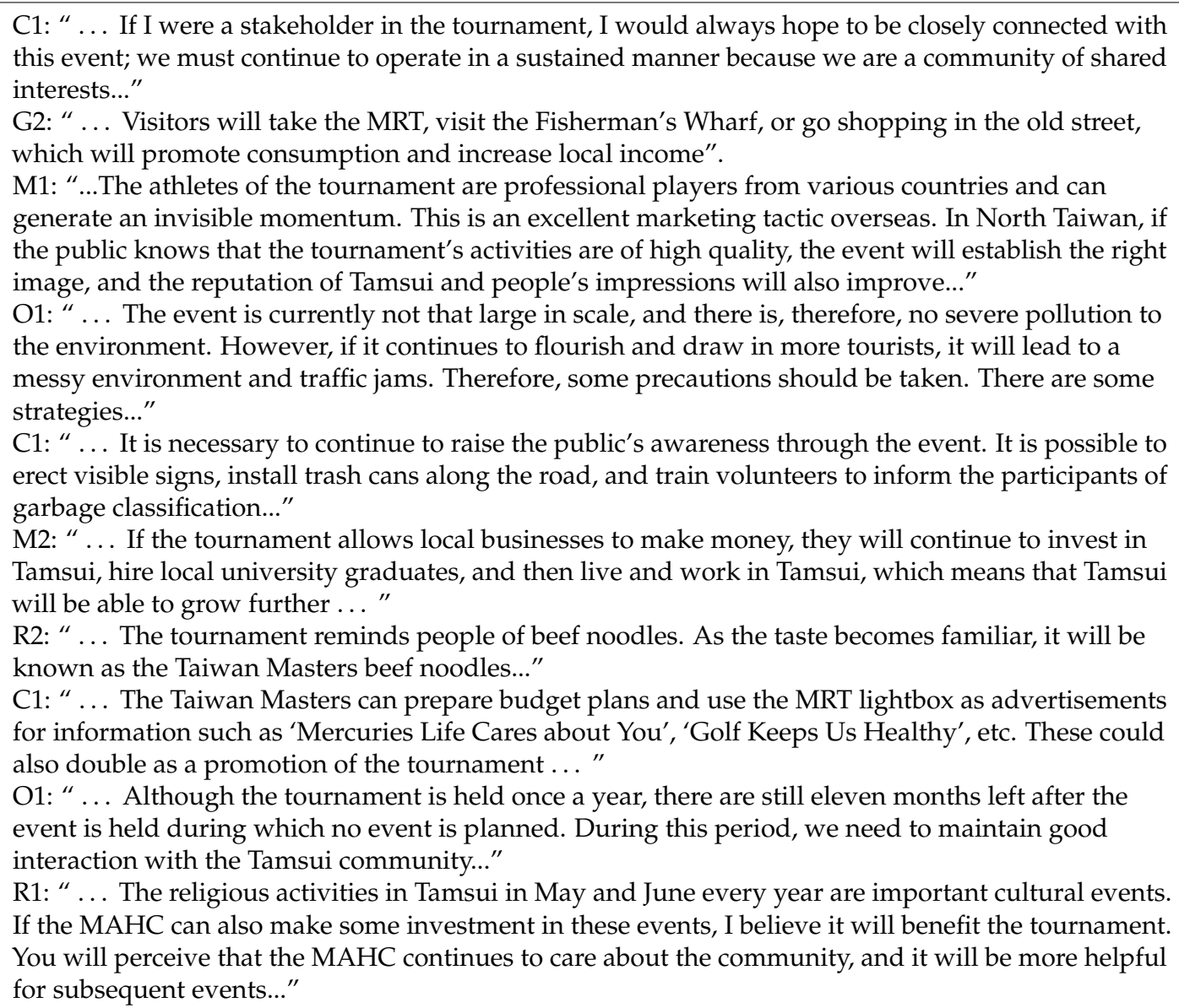 \\
\hline
\end{tabular}

To promote the sustainable development of regional tourism, the HSE should allow all stakeholders to cultivate a bond through the overall activities. To be able to continue hosting the event, the event owner should have the ambition and foresight to understand the needs of the community. As the C1 said, "... The MAHC can make plans to cultivate local middle and elementary schools and set up golf training classes to train local golf players".

In addition, event owners can use their local diversified management experience and brand to continue to invest in local businesses to leverage commercial marketing activities. For example, the local government could incorporate the event into local festivals to integrate the unique culture and educational resources of the region. This could not only promote golf activities during the non-event period but also supplement the government's sports policy. By cooperating with regional universities and adding innovative elements to the activity plan of HSE, it will promote the sustainable development of sports, tourism and cultural traditions in Tamsui, and create a win-win situation for the industry, government, and academia.

\subsection{The Critical Factors Facilitating Sustainable Development}

In order to facilitate the sustainable development of regional tourism, the features, scenery, and cultural environment of the venue where a sporting event is held cannot be ignored. If the HSE can be held continuously, it will naturally help the sustainable development of tourism in the region, and all the stakeholders of the tournament can receive the benefits of sustainability. It is necessary to create volunteer and cultural jobs through an HSE. Furthermore, those interested in golf are a potential workforce. The factors 
that hinder the sustainable development of regional tourism are few, and they mainly come from the external environment (e.g., economic prosperity). When the economy is in a recession, the owners and sponsors may be reluctant to continue investing in hosting the tournament. In addition, golf is less popular than other ball games, and it is generally regarded as an aristocratic sport in Taiwan. The general public is not motivated to be participants or spectators. If the series activities of sporting events lack innovation and attractiveness, it will reduce people's revisit intention. These results also echo the views of Getz [38], Getz et al. [39], and Frost [31], who have asserted that traditional cultural activities are a crucial factor in attracting tourists.

\subsection{The Role of HSE Stakeholder Groups in Realizing Regional Development Goals}

The goal of promoting tourism development in the Tamsui area is to improve the public image of Tamsui because it is an essential cultural site in Northern Taiwan. Understanding Tamsui first through sightseeing and then by caring about it will not only contribute to the local economy but also help with the promotion and preservation of Taiwanese culture. Among these stakeholder groups, the vision of the tournament owner (i.e., the Foundation for Taiwan Masters Golf Tournament) is critical to the sustainable operation of the event. The ultimate purpose of hosting this HSE is to leverage the historical value and glory of Taiwanese golf and make the "Taiwan Masters" one of the three major golf tournaments in Taiwan. The tournament also reaches out to local elementary schools, high schools, and universities. Every year, hundreds of students come to the event to watch the game, and this helps cultivate a positive atmosphere. From the perspective of marketing, regional sponsor brands can be integrated into the lives of residents through the long-term operation of the tournament. This could establish a sense of brand identity among the residents, conducive to the expansion of local business circles.

Regarding residents' perspective, the 42 boroughs of Tamsui could also be involved, and the borough chief could lead the residents to participate in the event. This could form a mutually supportive circle for event owners, sponsors, and residents. As the event's exposure and popularity increase, it will attract more people to the venue to watch the game and simultaneously visit Tamsui, thereby promoting the sustainable development of sport tourism. Therefore, it is necessary to ensure coordination, integration, and organization among interested groups.

\subsection{Sustained Benefits for Regional Tourism Development after the HSE}

When HSE athletes are professional players from various countries, they can generate intangible momentum, which is an excellent marketing tactic overseas. For the region itself, when more tourists know that there is a series of HSE activities every year, they also recognize this as a high-quality event. This creates a connection between the organizer and the region's public impression, and thus, a reputation is established. It also derives considerable benefits for the development of regional tourism, which include the creation of local attachment to Tamsui, cultural recognition of the region, and attractiveness of local domestic tourism. There are contributions to the advancement of the corporate image and the sustainable operation of regional business circles because more foreign tourists or consumers will be familiar with the HSE. Additionally, for co-organizers (such as schools), participation in the preparation of the event can continuously improve the image and reputation of the organization itself.

In this case, all the interviewees agreed that hosting the HSE has little impact on the environment of Tamsui. Almost all residents in various regions in Taiwan understand the concept of the 3Rs (reduce, reuse, and recycle). For golf tournaments, there is virtually no problem with pollution. With proper management in advance, the goal of a sustainable environment is not difficult to achieve. In addition, the HSE shares a close relationship with the sustainable development of human resource management of the regional co-organizers. Schools constitute a source of human resources and volunteers for the main event. The tournament can involve students as interns and offer volunteering opportunities. Local 
sports organizations could also be involved to appeal to residents in Tamsui to participate as volunteers. The sustainable development of the tournament includes continuous learning of new professional competencies and innovations. Volunteer training, which emphasizes service attitude and quality, is an essential foundation for sustainable human development.

In addition to driving more people to participate in activities related to sporting events, HSEs can promote sales at nearby hotels, restaurants, department stores, and souvenir shops. Even the real estate industry will flourish due to tourism. Therefore, strengthening the influence and sustainability of the HSE will be highly effective in promoting the marketing and development of the real estate industry. Moreover, it is necessary to maintain public relations and advertising expenses with the stakeholders of the tournament, even off-season. Event owners' continued investment in the region is crucial. They need to invest during the tournament and in the community outside the event. For example, it is possible to plan some cultural and religious activities for the cooperating entities of the event and use public facilities for marketing and advertising, so that event stakeholders are closely integrated with the features of regional tourism.

\section{Conclusions}

5.1. Findings

Although hosting sporting events has received considerable attention, previous studies had little focus on sustainable development strategies for regional tourism. To fill the research gap, this study has concluded four strategic perspectives of stakeholders that are corresponding to the claims made by Chalip [59] and Kelly and Fairley [91]. It means that the HSE could be a vehicle to promote the sustainable development of regional tourism. To achieve the goal of reviving the sustainable development of local tourism, it is necessary to cultivate effective synergy between local business activities, sporting event organizers, and stakeholders to create a specific atmosphere of festivity. Therefore, as far as HSE supply is concerned, the hosting of HSEs in Tamsui should be integrated into tourism promotion models as appropriate in order to establish regional sport tourism characteristics. Moreover, the four strategic perspectives proposed based on in-depth interviews correspond to the role of HSEs in a community and tourism environment proposed by Getz et al. [39]. Furthermore, the hosting of HSEs should create better coordination among event organizers and stakeholders related to the tourism industry, to set the development goals and proper execution processes to meet the needs of regional sustainable development.

\subsection{Managerial Implications}

This study revealed the stakeholders' perspectives on the roles and strategic outlook of HSEs with regards to the development of sustainable tourism. For stakeholders, HSEs are a new means for the promotion of sustainability in the development of tourism. The strategic outlook put forward by this study can help HSE owners or local governments to choose and host suitable events, thereby providing a reference for sporting events for the development of tourism in other specific regions. From the perspective of the supply side, whether an HSE successfully induces sustainable development in domestic tourism is closely connected to the mission of the event organizers and the involvement of stakeholders. The results show that although HSE stakeholders have addressed different dimensions of strategic views on the benefits of sporting events, the ultimate goals remain similar.

The MTMIGT has been generally recognized for its contribution to the sustainable development of Tamsui tourism. The strategies for sustainable development, including the linkage and cooperation of stakeholders such as the industry, governments, and academia, are highly critical. Through the promotion of governmental sport policies combined with the resources of HSE stakeholders, an overall atmosphere is created. The HSE is integrated into local festivals to make use of the unique cultural and geographical environment, and sporting resources of the region, to continue to help golf activities take root locally. Simultaneously, innovative elements can be incorporated into activity planning, so that 
HSEs will have a sense of integrity and consistency with existing sightseeing spots, festivals, culture, experience, and accommodation, thereby shaping the uniqueness of HSEs and regional tourism. On this basis, it is also possible in the future to consider setting up a Destination Marketing Organization (DMO) in the region, as an entity to promote the leverage strategy of HSEs and the sustainable development of tourism, to implement the value creation of sports, tourism, and inherent cultural traditions in Tamsui. That is, the sporting event organizer should design and manage the event image to fit the regional culture and traditional customs so that they can build the HSE as a vehicle for promoting the sustainable development of regional tourism.

\subsection{Limitations and Further Research Suggestions}

This study emphasized the role of hosting HSEs in the direction of sustainable development of regional tourism. However, only a qualitative analysis for a single HSE in a specific region, Tamsui, was conducted. The inferences and applications may therefore be limited due to the characteristics of HSEs, and the unique local humanities and geographical environment. Further studies may introduce the grounded theoretical model to compare different types of HSEs in other regions and explore the relationship between HSEs and the sustainable development of tourism. Moreover, it may be possible to utilize a longitudinal approach to examine how the leveraging strategies of HSEs could change the behavioral preferences of tourists, and illustrate how HSEs could benefit the sustainable development of tourism in a region/area.

Funding: This research was funded by the Ministry of Science and Technology, Taiwan; grant number MOST 108-2410-H-156-007.

Institutional Review Board Statement: Not applicable.

Informed Consent Statement: Not applicable.

Data Availability Statement: Not applicable.

Conflicts of Interest: The authors declare no conflict of interest.

\section{References}

1. UNWTO. UNWTO International Conference on Tourism and Sports; UNWTO: Madrid, Spain, 2016; Available online: http:// asiapacific.unwto.org/event/unwto-international-conference-tourism-and-sports (accessed on 14 November 2020).

2. UNWTO. Making Tourism More Sustainable—A Guide for Policy Makers; UNWTO: Madrid, Spain, 2005; Available online: https: //www.e-unwto.org/doi/book/10.18111/9789284408214 (accessed on 6 March 2021).

3. Roman, M.; Roman, M.; Niedziółka, A. Spatial diversity of tourism in the countries of the European Union. Sustainability 2020, 12, 2713. [CrossRef]

4. Gu, X.; Hunt, C.A.; Lengieza, M.L.; Niu, L.; Wu, H.; Wang, Y.; Jia, X. Evaluating residents' perceptions of nature-based tourism with a factor-cluster approach. Sustainability 2021, 13, 199. [CrossRef]

5. Csobán, K.V.; Serra, G. The role of small-scale sports events in developing sustainable sport tourism-A case study of fencing. Appl. Stud. Agribus. Commer. 2014, 8, 17-22. [CrossRef]

6. Preuss, H. The Economics of Staging the Olympics: A Comparison of the Games, 1972-2008; Elgar, E., Ed.; Cheltenham: Northampton, MA, USA, 2004.

7. Toohey, K.; Veal, A.J. The Olympic Games: A Social Science Perspective; CABI: Cambridge, MA, USA, 2007.

8. Clark, R.; Misener, L. Understanding urban development through a sport events portfolio: A case study of London, Ontario. J. Sport Manag. 2015, 29, 11-26. [CrossRef]

9. Haddad, E.A.; Haddad, P.R. Major sport events and regional development: The case of the Rio de Janeiro 2016 Olympic Games. Reg. Sci. Policy Pract. 2010, 2, 79-95. [CrossRef]

10. Triantafyllidis, S.; Darvin, L. Mass-participant sport events and sustainable development: Gender, social bonding, and connectedness to nature as predictors of socially and environmentally responsible behavior intentions. Sustain. Sci. 2020. [CrossRef]

11. Lee, C.K.; Lee, Y.K.; Lee, B.K. Korea's destination image formed by the 2002 World Cup. Ann. Tour. Res. 2005, 32, 839-858. [CrossRef]

12. Brown, G.; Smith, A.; Assaker, G. Revisiting the host city: An empirical examination of sport involvement, place attachment, event satisfaction and spectator intentions at the London Olympics. Tour. Manag. 2016, 55, 159-172. [CrossRef]

13. Shin, H.B. Unequal cities of spectacle and mega-events in China. City 2012, 16, 728-744. [CrossRef]

14. Timberlake, M.; Wei, Y.D.; Ma, X.; Hao, J. Global cities with Chinese characteristics. Cities 2014, 41, 162-170. [CrossRef] 
15. $\mathrm{Wu}, \mathrm{Y} . ; \mathrm{Li}, \mathrm{X} . ; \mathrm{Lin}, \mathrm{G} . \mathrm{C}$. Reproducing the city of the spectacle: Mega-events, local debts, and infrastructure-led urbanization in China. Cities 2016, 53, 51-60. [CrossRef]

16. Flyvbjerg, B.; Stewart, A. Olympic proportions: Cost and cost overrun at the Olympics 1960-2012. In Saïd Business School Working Paper; University of Oxford: Oxford, UK, 2012; Available online: http:/ / eureka.sbs.ox.ac.uk/4943/1/SSRN-id2382612_(2).pdf (accessed on 10 August 2020).

17. Kassens-Noor, E.; Lauermann, J. How to bid better for the Olympics: A participatory mega-event planning strategy for local legacies. J. Am. Plan. Assoc. 2017, 83, 335-345. [CrossRef]

18. Lin, H.W.; Lu, H.F. A longitudinal assessment on the economic effects of hosting major sporting events. Appl. Econ. 2018, 50, 6085-6099. [CrossRef]

19. Müller, M. After Sochi 2014: Costs and impacts of Russia's Olympic Games. Eurasian Geogr. Econ. 2014, 55, 628-655. [CrossRef]

20. Tien, C.; Lo, H.C.; Lin, H.W. The economic benefits of mega events: A myth or a reality? A longitudinal study on the Olympic Games. J. Sport Manag. 2011, 25, 11-23. [CrossRef]

21. Collins, A.; Jones, C.; Munday, M. Assessing the environmental impacts of mega sporting events: Two options? Tour. Manag. 2009, 30, 828-837. [CrossRef]

22. Du Preez, E.; Heath, E. Determining the influence of the social versus physical context on environmentally responsible behaviour among cycling spectators. J. Sport Tour. 2016, 20, 123-143. [CrossRef]

23. Kim, H.J.; Gursoy, D.; Lee, S.B. The impact of the 2002 World Cup on South Korea: Comparisons of pre- and post-Games. Tour. Manag. 2006, 27, 86-96. [CrossRef]

24. Triantafyllidis, S.; Ries, R.J.; Kaplanidou, K. Carbon dioxide emissions of spectators' transportation in collegiate sporting events: Comparing on-campus and off-campus stadium locations. Sustainability 2018, 10, 241. [CrossRef]

25. Gibson, H.J.; Kaplanidou, K.; Kang, S.J. Small-scale event sport tourism: A case study in sustainable tourism. Sport Manag. Rev. 2012, 15, 160-170. [CrossRef]

26. Higham, J. Sport as an avenue of tourism development: An analysis of the positive and negative impacts of sport tourism. Curr. Issues Tour. 1999, 2, 82-90. [CrossRef]

27. Tourism Bureau MOTC. Annual Statistical Report on Tourism 2019. Available online: https://admin.taiwan.net.tw/Handlers/ FileHandler.ashx?fid=4cc95658-0620-43d4-bbec-12f97c836138\&type=4\&no=1 (accessed on 20 February 2020).

28. Foundation for Taiwan Masters Golf Tournament. 2020. Available online: http://www.taiwan-masters.com.tw/index.asp (accessed on 20 December 2020).

29. Koenigstorfer, J.; Bocarro, J.N.; Byers, T.; Edwards, M.B.; Jones, G.J.; Preuss, H. Mapping research on legacy of mega sporting events: Structural changes, consequences, and stakeholder evaluations in empirical studies. Leis. Stud. 2019, 38, 729-745. [CrossRef]

30. Taks, M.; Chalip, L.; Christine, G.B. Impacts and strategic outcomes from non-mega sport events for local communities. Eur. Sport Manag. Q. 2015, 15, 1-6. [CrossRef]

31. Frost, W. Events and tourism. In Routledge Handbook of Events; Page, S., Connell, J., Eds.; Routledge: London, UK, 2012; pp. 75-86.

32. Ritchie, J.R.B.; Beliveau, D. Hallmark events: An evaluation of a strategic response to seasonality in the travel market. J. Travel Res. 1974, 13, 14-20. [CrossRef]

33. Ritchie, J.R.B. Assessing the impact of hallmark events: Conceptual and research issues. J. Travel Res. 1984, 23, 2-11. [CrossRef]

34. Graham, S.; Goldblatt, J.; Delpy, L. The Ultimate Guide to Sport Event Management and Marketing; Irwin: Chicago, IL, USA, 1995.

35. Getz, D. Event Management and Event Tourism; Cognizant Communication Corporation: New York, NY, USA, 1997.

36. Ritchie, J.R.B.; Crouch, G. The Competitive Destination: A Sustainable Tourism Perspective; CABI: Wallingford, UK, 2003.

37. Saunders, M.; Lewis, P.; Thornhill, A. Research Methods for Business Students, 4th ed.; Financial Times Prentice-Hall: London, $\mathrm{UK}, 2007$.

38. Getz, D. Festivals, Special Events, and Tourism; Van Nostrand Reinhold: New York, NY, USA, 1991.

39. Getz, D. Event Management and Event Tourism, 2nd ed.; Cognizant: New York, NY, USA, 2005.

40. Getz, D.; Svensson, B.; Peterssen, R.; Gunnervall, A. Hallmark events: Definition, goals and planning process. Int. J. Event Manag. Res. 2010, 7, 47-67.

41. Bramwell, B. A sport mega-event as a sustainable tourism development strategy. Tour. Recreat. Res. 1997, 22, 13-19. [CrossRef]

42. Kiani, M.S.; Nazari, L.; Shahbazpour, L. Sport tourism and sustainable local development for host cities for sporting events. Am. J. Sport Sci. 2019, 7, 7-10. [CrossRef]

43. Malchrowicz-Mośko, E.; Poczta, J. A small-scale event and a big impact-Is this relationship possible in the world of sport? The meaning of heritage sporting events for sustainable development of tourism-Experiences from Poland. Sustainability 2018, 10, 4289. [CrossRef]

44. Preuss, L. Buying into our future: Sustainability initiatives in local government procurement. Bus. Strategy Environ. 2007, 16, 354-365. [CrossRef]

45. Thomson, A.; Cuskelly, G.; Toohey, K.; Kennelly, M.; Burton, P.; Fredline, L. Sport event legacy: A systematic quantitative review of literature. Sport Manag. Rev. 2019, 22, 295-321. [CrossRef]

46. Owen, J.G. Estimating the cost and benefit of hosting Olympic Games: What can Beijing expect from its 2008 Games? Ind. Geographer. 2005, 3, 1-18. 
47. Bouchet, P.; Lebrun, A.; Auvergne, S. Sport tourism consumer experiences: A comprehensive model. J. Sport Tour. 2004, 9, 127-140. [CrossRef]

48. Matheson, V.A. Contrary evidence on the economic effect of Super Bowl on the victorious city. J. Sport. Econ. 2005, 6, 420-428. [CrossRef]

49. Ziakas, V.; Costa, C.A. The use of an event portfolio in regional community and tourism development: Creating synergy between sport and cultural events. J. Sport Tour. 2011, 16, 149-175. [CrossRef]

50. Sherwood, P. A Triple Bottom Line Evaluation of the Impact of Special Events: The Development of Indicators. Unpublished Doctoral Dissertation, Victoria University, Melbourne, Australia, 2007. Available online: https://1library.net/document/y80ldj0 q-triple-line-evaluation-impact-special-events-development-indicators.html (accessed on 14 November 2020).

51. Barker, M.; Page, S.J.; Meyer, D. Evaluating the impact of the 2000 America's cup on Auckland, New Zealand. Event Manag. 2002, 7, 79-92. [CrossRef]

52. Fredline, E. Host and guest relations and sport tourism. In Sport Tourism: Concepts and Theories; Gibson, E., Ed.; Routledge: London, UK, 2006.

53. Leonardsen, D. Planning of mega events: Experiences and lessons. Plan. Theor. Pract. 2007, 8, 11-30. [CrossRef]

54. Shipway, R. Sustainable legacies for the 2012 Olympic Games. J. R. Soc. Promo. Health 2007, 127, 119-124. [CrossRef] [PubMed]

55. Garcia, B. More than a game: Olympic arts programming can increase local participation. Cult. Olymp. 2004, 6, 35-40.

56. Shipway, R.; Brown, L. Challenges for a regional cultural programme of the London 2012 Games. Cult. Olymp. 2007, 9, 21-35.

57. Frey, M.; Iraldo, F.; Melis, M. The impact of wide-scale sport events on local development: An assessment of the XXth Torino Olympics through the sustainability report. SSRN 2008. [CrossRef]

58. Wang, W.; Theodoraki, E. Mass sport policy development in the Olympic City: The case of Qingdao-Host to the 2008 sailing regatta. J. R. Soc. Promo. Health 2007, 127, 125-132. [CrossRef]

59. Burgan, B.; Mules, T. Economic impact of sporting events. Ann. Tour. Res. 1992, 19, 700-710. [CrossRef]

60. Chalip, L. Towards social leverage of sport events. J. Sport Tour. 2006, 11, 109-127. [CrossRef]

61. Waitt, G. Social impacts of the Sydney Olympics. Ann. Tour. Res. 2003, 30, 194-215. [CrossRef]

62. Kim, S.S.; Morrison, A.M. Change of images of South Korea among foreign tourists after the 2002 FIFA World Cup. Tour. Manag. 2005, 26, 233-247. [CrossRef]

63. Carey, M.; Mason, D.S.; Misener, L. Social responsibility and the Competitive Bid Process for Major Sporting Events. J. Sport Soc. Issues 2011, 35, 246-263. [CrossRef]

64. Gursoy, D.; Kendall, K.W. Hosting mega events: Modeling locals' support. Ann. Tour. Res. 2006, 33, 603-623. [CrossRef]

65. Whitson, D.; Horne, J. Part 2 The Glocal Politics of Sports Mega-Events: Underestimated costs and overestimated benefits? Comparing the outcomes of sports mega-events in Canada and Japan. Sociol. Rev. 2006, 54, 71-89. [CrossRef]

66. Kim, W.; Jun, H.M.; Walker, M.; Dran, D. Evaluating the perceived social impacts of hosting large-scale sport tourism events: Scale development and validation. Tour. Manag. 2015, 48, 21-32. [CrossRef]

67. Garnham, B. Ranfurly Shield Rugby: An investigation into the impacts of sporting event on a provincial city, the case of New Plymouth, Taranaki, New Zealand. Festiv. Manag. Event Tour. 1996, 4, 145-149. [CrossRef]

68. Hsu, B.C.Y.; Wu, Y.F.; Chen, H.W.; Cheung, M.L. How Sport Tourism Event Image Fit Enhances Residents' Perceptions of Place Image and Their Quality of Life. Sustainability 2020, 12, 8227. [CrossRef]

69. Soutar, G.; McLeod, P. Residents' perceptions on impact of the America's Cup. Ann. Tour. Res. 1993, 20, 571-582. [CrossRef]

70. Andersson, T.D.; Lundberg, E. Commensurability and sustainability: Triple impact assessments of a tourism event. Tour. Manag. 2013, 37, 99-109. [CrossRef]

71. Kaplanidou, K.; Vogt, C. The Interrelationship between sport event and destination image and sport tourists' behaviours. J. Sport Tour. 2007, 12, 183-206. [CrossRef]

72. May, V. Environmental implications of the 1992 Winter Olympic Games. Tourism Manag. 1995, 16, 269-275. [CrossRef]

73. Pedersen, P.M.; Parks, J.B.; Quarterman, J.; Thibault, L. Contemporary Sport Management, 4th ed.; Human Kinetics: Champaign, IL, USA, 2010.

74. Goeldner, C.; Ritchie, J.R.B. Tourism: Practices, Principles, Philosophies; Wiley: New York, NY, USA, 2003.

75. Bourdeau, P.; Corneloup, J.; Mao, P. Adventure sports and tourism in the French mountains: Dynamics of change and challenges for sustainable development. In Sport Tourism: Interrelationships, Impacts and Issues; Ritchie, B., Adair, D., Eds.; Channel View: Clevedon, UK, 2004; pp. 101-116.

76. Palmer, C. More than just a game: The consequences of golf tourism. In Sport Tourism: Interrelationships, Impacts and Issues; Ritchie, B., Adair, D., Eds.; Channel View: Clevedon, UK, 2004; pp. 117-134.

77. Lim, C.C.; Patterson, I. Sport tourism on the islands: The impact of an international mega golf event. J. Sport Tour. 2008, 13, 115-133. [CrossRef]

78. Ahmed, F.; Moodley, V.; Sookrajh, R. The environmental impacts of beach sport tourism events: A case study of the Mr. Price Pro surfing event, Durban, South Africa. Afr. Insight 2008, 38, 73-85. [CrossRef]

79. Collins, A.; Flynn, A. Measuring the environmental sustainability of a major sporting event: A case study of the FA Cup final. Tour. Econ. 2008, 14, 751-768. [CrossRef]

80. Collins, A.; Munday, M.; Roberts, A. Environmental consequences of tourism consumption at major events: An analysis of the UK stages of the 2007 Tour de France. J. Travel Res. 2012, 51, 577-590. [CrossRef] 
81. Zhang, Y.; Park, K.S. How to develop a sustainable and responsible hallmark sporting event?-Experiences from tour of Qinghai Lake International Road Cycling Race, using IPA method. Int. J. Tour. Sci. 2015, 15, 59-69. [CrossRef]

82. Andersson, T.; Armbrecht, J.; Lundberg, E. Estimating use and non-use values of a music festival. Scand. J. Hosp. Tour. 2012, 12, 215-231. [CrossRef]

83. Beesley, L.G.; Chalip, L. Seeking (and not seeking) to leverage mega-sport events in non-host destinations: The case of Shanghai and the Beijing Olympics. J. Sport Tour. 2011, 16, 323-344. [CrossRef]

84. Bell, B.; Gallimore, K. Embracing the games? Leverage and legacy of London 2012 Olympics at the sub-regional level by means of strategic partnerships. Leis. Stud. 2015, 34, 720-741. [CrossRef]

85. Grix, J. Image leveraging and sports mega-events: Germany and the 2006 FIFA world Cup. J. Sport Tour. 2012, 17, 289-312 [CrossRef]

86. Smith, A. Leveraging sport mega-events: New model or convenient justification? J. Policy Res. Tour. Leis. Events. 2014, 6, 15-30. [CrossRef]

87. Tichaawa, T.M.; Bob, U. Leveraging mega-events beyond the host nation: A case study of the 2010 FIFA world Cup African legacy programme in Cameroon and Nigeria. Leisure Stud. 2015, 34, 1-16. [CrossRef]

88. O’Brien, D.; Chalip, L. Executive training exercise in sport event leverage. Int. J. Culture Tour. Hosp. Res. 2007, 1, 296-304. [CrossRef]

89. O'Brien, D.; Chalip, L. Sport Events and Strategic Leveraging: Pushing towards the Triple Bottom Line. In Tourism Management: Analysis, Behaviour and Strategy; Woodside, A., Martin, D., Eds.; CABI: Oxfordshire, UK, 2008; pp. 318-338.

90. Chalip, L.; Leyns, A. Local business leveraging of a sport event: Managing an event for economic benefit. J. Sport Manag. 2002, 16, 132-158. [CrossRef]

91. O'Brien, D. Points of Leverage: Maximizing host community benefit from a regional surfing festival. Eur. Sport Manag. Q. 2007, 7, 141-165. [CrossRef]

92. Kelly, D.M.; Fairley, S. What about the event? How do tourism leveraging strategies affect small-scale events? Tour. Manag. 2018, 64, 335-345. [CrossRef]

93. Kruger, M.; Saayman, M. Creating a memorable spectator experience at the Two Oceans Marathon. J. Sport Tour. 2012, 17, 63-77. [CrossRef]

94. Kaplanidou, K.; Gibson, H.J. Predicting behavioral intentions of active event sport tourists: The case of a small-scale recurring sports event. J. Sport Tour. 2010, 15, 163-179. [CrossRef]

95. Misener, L.; Mason, D.S. Creating community networks: Can sporting events offer meaningful sources of social capital? Manag. Leis. 2006, 11, 39-56. [CrossRef]

96. Misener, L.; Mason, D.S. Fostering community development through sporting events strategies: An examination of urban regime perceptions. J. Sport Manag. 2009, 23, 770-794. [CrossRef]

97. Misener, L. Leveraging parasport events for community participation: Development of a theoretical framework. Eur. Sport Manag. Q. 2015, 15, 1-22. [CrossRef]

98. Freeman, R.E. Strategic Management: A Stakeholder Approach; Pitman: Boston, MA, USA, 1984.

99. Donaldson, T.; Preston, L.E. The stakeholder theory of the corporation: Concepts, evidence, and implications. Acad. Manag. Rev. 1995, 20, 65-91. [CrossRef]

100. Jones, T.M.; Wicks, A.C. Convergent stakeholder theory. Acad. Manag. Rev. 1999, 24, 206-221. [CrossRef]

101. Reid, S.; Arcodia, C. Understanding the role of the stakeholder in event management. J. Sport Tour. 2002, 7, 20-22. [CrossRef]

102. Reid, S. The social consequences of rural events: The Inglewood Olive Festival. In Proceedings of CAUTHE: Creating Tourism Knowledge; Arcodia, C.C.C., Solnet, D., Whitford, M., Eds.; Common Ground Publishing: Brisbane, QLD, Australia, 2004; pp. 607-621.

103. Hede, A.M. Food and wine festivals: Stakeholders, long-term outcomes and strategies for success. In Food and Wine Festivals and Events around the World: Development, Management and Markets; Butterworth Heinemann: Oxford, UK, 2008; pp. 85-100. [CrossRef]

104. Parent, M.M. Evolution and issue patterns for major-sport-event organizing committees and their stakeholders. J. Sport Manag. 2008, 22, 135-164. [CrossRef]

105. Clarkson, M.E. A stakeholder framework for analyzing and evaluating corporate social performance. Acad. Manag. Rev. 1995, 20, 92-117. [CrossRef]

106. Covell, D. Attachment, allegiance and a convergent application of stakeholder theory to Ivy League athletics. Int. Sports J. 2004, 8, 14-26.

107. Parent, M.M. Stakeholder perceptions on the democratic governance of major sports events. Sport Manag. Rev. 2016, 19, 402-416. [CrossRef]

108. Bowdin, G.; Allen, J.; O’Toole, W.; Harris, R.; McDonnell, I. Events Management, 2nd ed.; Routledge: London, UK, 2006.

109. Leopkey, B.; Parent, M.M. The governance of Olympic legacy: Process, actors and mechanisms. Leis. Stud. $2017,36,438-451$. [CrossRef]

110. Bryman, A. Social Research Methods; Oxford University Press: Oxford, UK, 2015. 